Article

\title{
Illegal Hunting of Prey Species in the Northern Section of Bardia National Park, Nepal: Implications for Carnivore Conservation
}

\author{
Babu Ram Bhattarai ${ }^{1,2, *}$, Wendy Wright ${ }^{2}$ and Ambika Pd. Khatiwada ${ }^{3}$ \\ 1 Department of National Parks \& Wildlife Conservation, Kathmandu 860, Nepal \\ 2 Faculty of Science and Technology, Federation University, Gippsland 3842, VIC, Australia; \\ wendy.wright@federation.edu.au \\ 3 National Trust for Nature Conservation-Bardia Conservation Programme, Thakurdwara 3712, Nepal; \\ ambika.pd.khatiwada@gmail.com \\ * Correspondence: bhattarai.babur@gmail.com; Tel.: +61-452-237-933
}

Academic Editors: Uttam Babu Shrestha, Binod Pokharel, Achyut Aryal, Basanta Raj Adhikari, Loknath Adhikari and Suman Aryal

Received: 1 November 2016; Accepted: 21 November 2016; Published: 29 November 2016

\begin{abstract}
We interviewed 48 people from communities around Bardia National Park in Nepal, including ex-hunters and protected area management professionals. The purpose of the interviews was to understand the motivations for, and the nature of, illegal hunting of prey species of iconic predators-tigers and leopards-in the northern section of the park. Participants reported that hunting of prey species occurs mostly in spring and autumn and is less common during the summer. In the past, hunting was primarily for the purposes of obtaining meat for household consumption. Since the introduction of a road network in the region, opportunities to sell wild meat at ad hoc "highway markets" have developed. The purported medicinal properties of wild meat was also cited as a driver for illegal hunting. Guns (mostly made locally, by hand) and dogs were reported to be commonly used. Protected area managers indicated that illegal hunting problems in the study area are associated with a lack of presence of park authorities, remoteness and underdevelopment and poverty of the community. Our study suggested that skills development training for local community members might reduce dependency of local people on wild meat, for both household consumption and for income, thereby reducing illegal hunting.
\end{abstract}

Keywords: Bardia; carnivore; illegal hunting; prey; wild meat

\section{Introduction}

Hunting of wildlife by humans (hereafter referred to as hunting) has long been a practice in many communities and still continues in many forms throughout the world [1-4]. At a time when human populations were small and wildlife were abundant, hunting was not a threat to the survival of animal populations. However, human populations have increased drastically since the start of the 20th century, and the pressures of reduced habitat availability are threatening many species worldwide [1,5-7]. Unsustainable hunting, for wild meat and highly valued wildlife parts used in traditional and alternative medicines, further threaten the survival of many species and lead towards local, regional and global extinction —of the hunted species as well as of their natural predators [8-11]. Where hunting is a threat to wildlife some wildlife conservation programs are actively working towards reducing it.

In South Asian countries including Nepal, traditional hunting of wildlife to meet cultural and household needs has been a practice since ancient times [12,13] and wild meat was an important traditional source of protein for humans $[3,10]$. In recent times, despite laws forbidding hunting, 
wild meat continues to fulfill the subsistence needs of many local communities as well as a "luxury demand" from wealthier people residing in urban areas. Hunting of wildlife was common throughout Nepal until the National Parks and Wildlife Conservation Act (NPWCA) was promulgated in 1973. Section 11 of the NPWCA banned the hunting of wildlife in protected areas without a license (permit). Several kinds of hunting permit are defined in the associated National Parks and Wildlife Conservation Regulations 1976 [14]; however, no permits have been issued since the establishment of the Department of National Parks and Wildlife Conservation in 1980 (Babu Bhattarai, pers. obs.). The Forest Act (1993) bans hunting in forests outside of protected areas [15,16]; and it is illegal for farmers to kill wildlife that intrude into crops. The issue of hunting in private forests is not addressed by law; however, such forests are very few in Nepal. Legal hunting of wildlife in Nepal is therefore practiced only in Dhorpatan Hunting Reserve [17] a $1325 \mathrm{~km}^{2}$ area in the Dhaulagiri Himal range of western Nepal, which attracts both Nepalese and foreign sports hunters who pay a significant fee to hunt a limited range of wild game species under license during certain seasons of the year.

Section 26 (6) of the NPWCA has provisions for fines of up to NRs 10,000 ( US \$100) or 24 months prison; or both, in cases where species other than protected species (as listed under schedule I of the Act), are killed. In cases where convictions relate to the killing of protected species, fines can be up to NRs100,000 ( US $\$ 1,000$ ) and the penalty may also include imprisonment up to 15 years (Section 26 (1) of NPWCA). Tigers, and several of the tiger's prey species in Bardia National Park are protected species (Table A1).

After the introduction of NPWCA (1973) and the Forest Act (1993), hunting reduced sharply inside protected areas in Nepal [18]. Outside of protected areas, the practice continued, resulting in most of the forests outside of the protected area system becoming almost entirely depleted of populations of large herbivores. Instances of hunting inside protected areas have also been documented [12] especially in the fringe areas and where vigilance of protection staff is minimal.

Globally, both legal and illegal hunting of wildlife directly affect populations of hunted species and indirectly affect populations of dependent species. In some circumstances, where hunting is practiced legally, based on sound scientific grounds, it can benefit biodiversity and assist conservation objectives $[17,19]$. On the other hand, illegal hunting of prey species has already affected populations of endangered carnivores such as tiger in Asia [20] and jaguar in America [21]. In these cases, hunting by humans is the sole reason for the absence of prey species. In recent years, leopards have become a problematic species throughout the middle hills region of Nepal. There are many anecdotes describing the intrusion of leopard into densely human populated cities. A lack of prey species is thought to have forced leopards to depend on pets and livestock, with occasional instances of human casualties [22].

This paper sheds light on illegal hunting (as defined by [23]) of prey species in the northern part of Bardia National Park and considers the implications of this for carnivore conservation. Prey species in this study refers to prey of tiger and leopard, and includes ungulate species (chital, sambar and barking deer, goral, wild boar) and primates (rhesus monkey, grey langur). The study explores questions around why people hunt, which species are commonly hunted, which animal parts are used for what purposes, where markets exist for the sale of animal products and what methods are employed for hunting of wildlife.

\section{Methods}

Study area: Bardia National Park (Figure 1) is rich in biodiversity, supporting populations of a variety of mammals. These include five species of deer (Spotted, Barking, Sambar, Swamp and Hog deer), two species of antelope (blue Bull and four-horned antelope), other ungulates (wild boar, goral) and primates (grey langur and rhesus monkey). Carnivorous mammals include large carnivores (tiger and leopard), meso carnivores (grey wolf, stripped hyena, golden jackal, fox), and in the aquatic environment, the Gangetic river dolphin. Several species of reptiles are also present, including Burmese python, gharial and mugger crocodiles (see Table A1 for scientific names of species mentioned in the text). More than four hundred species of birds can be found in the park, including some globally 
threatened species such as great hornbill and bengal florican [24]. Two major rivers: Karnali in the west and Babai in the east have created alluvial flood plain grasslands [25], which are highly productive and rich in biodiversity. The northern part of the park includes the Siwalik Range (also called the Siwalik Hills or Outer Himalayas). This includes areas (Bhavar) where pebbles and boulders accumulate, brought by the Himalayan rivers. Here, the water table is very low and the area is less productive and less biodiverse. The southern plains areas of the park are characterized by highly fertile land [26]. Along the rivers, riverine forest of Sindure, Gutel, Sisau, and Khayar (see Table A1 for English and scientific names in Appendix A) are dominant whereas the inner forests, further away from the rivers, are dominated by Sal [27]. In the Siwalik region, forests of Khasru and Sallo dominate.

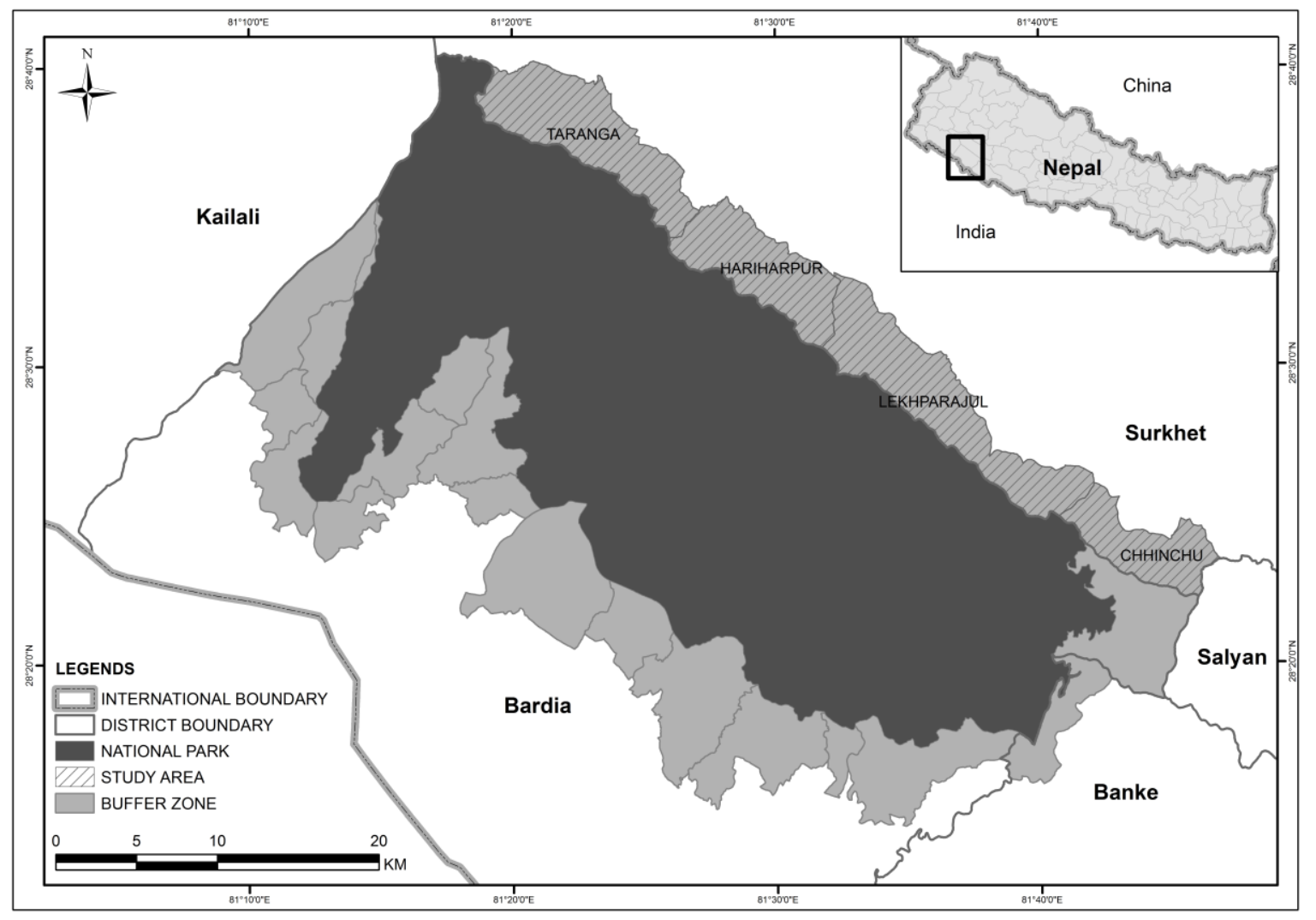

Figure 1. Bardia National Park and the surrounding buffer zone. Our study area comprised the communities of Taranga, Hariharpur, Lekhparajul and Chhinchu, located within the northern buffer zone area.

The National Park is $968 \mathrm{sq} \mathrm{km}$ in area and a buffer zone surrounding the park adds another $507 \mathrm{sq} \mathrm{km}$ (see Figure 1). There are no human settlements or agricultural land inside the boundaries of the national park (settlements were relocated during the establishment phase of the park, see [26]). However, a mixed heterogeneous society, including indigenous Tharu people and migrants from the hill areas (Pahade) live within the buffer zone areas. Settlements, agricultural land and community forests are all embedded within the buffer zone areas. Around 120,000 people utilize the park and its buffer zone forests for various resources to support their livelihoods [28]. The buffer zone area comprises fragile Siwalik where landslides commonly occur. During 2014, the landslides in the Siwalik caused flooding in the Bheri River, which claimed the lives of nearly 50 people and destroyed 321 houses in four village development committees within the study area (unpublished data of District Administration Office, Surkhet). The settlements adjacent to the northern part of the park (the study area) were established relatively recently. Migrants from the adjacent hills moved into this location about two hundred years ago. At the time of arrival, migrant people chose to settle in locations 
where land was either freely available, or available at a very low cost, and where forest resources were available to support livelihoods, which were resourced via subsistence agriculture and animal husbandry. Often, people migrate to lower, more fertile land after they have earned some money to purchase land in more productive locations. Therefore, the study area is somewhat of a transit settlement for economic migrants from the hill areas. This study was conducted in the northern part of the buffer zone surrounding Bardia National Park.

Four village development committees (VDCs) (the VDC is the smallest local government unit) comprised our study area. These were the Taranga, Chhinchu, Hariharpur and Lekhparajul VDCs, all located within the Surkhet district. Taranga is the most remote of the four VDCs within our study. Local people from Taranga would need to walk for three to four hours in order to reach the nearest road. The other three VDCs are not quite so remote, but none, except Chhinchhu, are serviced directly by roads. The Kohalpur-Surkhet highway, constructed in late 1980s, passes through Chhinchhu and is approximately $30 \mathrm{~km}$ away from the most remote part of the study area.

Interviews: Seventeen Village Development Committees (VDCs) are embedded in the buffer zone of Bardia National Park (BNP). From among these we selected four (Chhinchu, Taranga, Lekhparajul and Hariharpur). These had only recently come under buffer zone jurisdiction (in 2010), though BNP was established in 1976 and buffer zones in other areas were declared in 1996.

We completed face-to-face interviews [29] with local people $(n=43)$ during May and June 2015. Participants included self-identified ex-hunters and other community members. Five professional protected area managers were also interviewed. As hunting within the park and within the buffer zone is now illegal, no questions about the participants' own current hunting practices were asked; and the hunting or poaching of protected species was not discussed. This approach addressed our concerns about non-participation, withdrawal from participation or reduced responses [30-32], and meant that we did not compromise our interviewees. Also, our objective was to explore the hunting of prey species of carnivores. We did not ask for the name of respondents; however, many introduced themselves during the interviews. Names volunteered in this way were not recorded. All questions were general and directed towards obtaining information about the nature of hunting activities rather than who was carrying out these activities.

We were also aware of a possible influence on the responses of the interviewees due to the researchers' affinity with a local conservation and sustainable development agency (National Trust for Conservation of Nature, NTNC). The final question, which was about whether participants felt that small-scale skills development training might reduce the occurrence of illegal hunting, was asked last so that questions regarding hunting and wildlife were addressed before the affiliation with NTNC was brought to the attention of the interviewee. However, it is possible that the affiliation was recognized and that interviewees chose to make statements that were intended to please the interviewers and increase the likelihood of future support of participants' communities by the NTNC.

Interviewees were recruited by placing notices about the project in public places and requesting volunteers. "Snowball sampling" was also applied, where volunteers recommended participation to several others in their community, some of whom subsequently volunteered. Several participants self-disclosed their own (past) participation in hunting activities.

Interviews were conducted at locations of the participants' own choosing, which included their own dwelling or at market places or community meeting places. Before we began each interview, we provided an explanatory statement about the research and asked for informed consent to conduct the interview. Most people agreed to participate; only very few people did not give consent and did not participate further. The interviews took approximately 20 to $30 \mathrm{~min}$ each.

Some demographic information about participants, such as their age, settlement history, nature and amount of land owned, livestock owned, etc., was sought. The main part of the interview was comprised of questions about:

1. which species of wildlife participants had seen locally,

2. how many animals hunters are likely to take in a year, 
3. whether hunting is more common in any particular season,

4. what methods of hunting are used,

5. which species are hunted,

6. why wildlife are hunted,

7. where wildlife products are sold and at what price, whether it is generally known that hunting is an illegal act,

8. whether access to some skills development training, may stop or reduce hunting activity,

9. what sorts of skills development training might help communities to reduce or stop hunting, etc.

We also interviewed five protected area management professionals (park rangers, warden and representatives from non-government conservation agencies) to find out:

1. whether they are aware of hunting occurring in BNP,

2. whether hunting is a past or a current practice,

3. whether hunting is more common in the northern section of the park and buffer zones,

4. whether there is a particular subgroup in the community which is considered to be more involved in hunting than others

5. how hunting can be reduced

6. whether the provision of small-scale skills development training for local people may be helpful in reducing their dependence on hunting.

Interview questions, recruitment methods and interview technique were all approved by the Human Research Ethics Committee of Federation University Australia (Project No. B15-051).

We also conducted several transect surveys in the forest areas nearest to settlements, seeking evidence of current hunting activities. Several transects, each approximately one kilometer long, were established in each forest area and traversed by two observers during daylight in December 2015. There were a total of 18 transects: seven were located near Taranga, five near Lekhparajul and six near Hariharpur. Since Chhinchu has only a very small area of forest, lying mostly along the highway, we did not conduct transect surveys in Chhinchu. A total of $38 \mathrm{~h}$ and $35 \mathrm{~min}$ was spent walking the transects and observing. Our objectives were to document any evidence of hunting activity, such as the remains of animal carcasses, the presence of meat drying huts and snares left by hunters. We also listened for the sound of gunshot, which may have indicated current hunting activity.

Our project team conducted a trial skills-training program, hosted by the NTNC. The program focused on solar panel and household electricity maintenance. Training was provided to 13 local youths with the aim of reducing the participants' dependency on hunting by increasing their skill sets and employability. One woman and 12 men participated in the program. They were aged approximately between 20 and 35, and were drawn from the four village development communities. The NTNC also hosted three conservation education sessions with local people focusing on the significance of conserving prey species in carnivore conservation.

\section{Results}

\subsection{Demography of the Interview Respondents}

We interviewed 43 local community respondents. The average age of the respondents was 32 (standard deviation $=10.33, n=42$ ); the youngest was 19 while the oldest was 60 years old. Not all participants answered all questions, where this is the case, the number of respondents is indicated. The majority of those interviewed were male $(67 \%)$ and respondents' professions were: farmers $(66 \%)$, businessman $(12 \%)$, school-teachers $(10 \%)$, others (10\% including students, social workers and activists) and public servants $(2 \%)$. The average landholding of the respondents was 7.14 ropani $(\mathrm{sd}=3.75$, the highest landholding was 16 ropani; 1 ropani of land is equivalent to 3561 sq meters) and, on average each person possessed one cow (range 4), 0.5 buffalo (range 2) and 12 goats (range 40). Respondents 
had been living in this location between 5 and 50 years. We also interviewed five protected area professionals. Three were from non-governmental organizations and two were from a government organization. Only one was female. These professionals were all university educated and originated from other areas of Nepal. They had been working in the area for between two and 15 years.

\subsection{Seasons and Reasons for Prey Hunting}

Most of the local community interviewees (74\%) had sighted wildlife (defined as large vertebrates) including tiger, leopard, Asian elephant, greater one-horned rhinoceros, sloth bear, golden jackal, Himalayan goral, sambar deer, barking deer, wild boar, spotted deer, porcupine, grey langur monkey and rhesus monkey. We asked participants to name animal species that were hunted in the area. Nine different prey species of tiger and leopard were named by participants: sambar deer, wild boar, spotted deer, barking deer, grey langur, rhesus monkey, porcupine, kalij pheasant and goral. Interviewees noted that sambar deer is the most preferred species for meat because it is a large animal and can provide more than $100 \mathrm{~kg}$ of wild meat; with less fat than wild boar. Wild boar was also reported to taste good, and the animal is also relatively large. Interviewees noted that spotted deer (chital) are gregarious and easy to capture in Khabar (a snare made from ropes). Unlike in other areas, the Siwalik region has a low abundance of chital, therefore they are not so frequently hunted like in the plains. Himalayan goral, which inhabits the Siwalik Mountains, is often hunted in this location. Although questions were not asked regarding protected species, a few respondents mentioned hunting of tiger, and rhinoceros. Several respondents told us that the number of leopard sightings, tiger signs (e.g. footprints, also known as pugmarks) and vocalizations of fox and jackal had decreased, and attributed this to prey hunting. They reported that these signs of carnivores have recently begun to increase again after a recent call for guns to be handed over to the park authority.

We attempted to explore the hunting frequency (total number of hunted animals in a particular year) but answers were vague and we failed to acquire this information. However, it was clear that hunting is a reasonably common activity. Interview participants reported that, prior to the establishment of buffer zones, hunting typically occurred at least twice a year, and the adult males of almost all households participated in hunting.

In response to questions about the seasonality of hunting, $41 \%$ participants indicated that spring was the season in which most hunting traditionally occurred. Autumn was named by $37 \%$ of the participants, winter by $10 \%$ of participants, and summer by $5 \%$ of participants. Seven percent of participants indicated that hunting occurred in all seasons $(n=41$ for this question, Figure 2$)$.

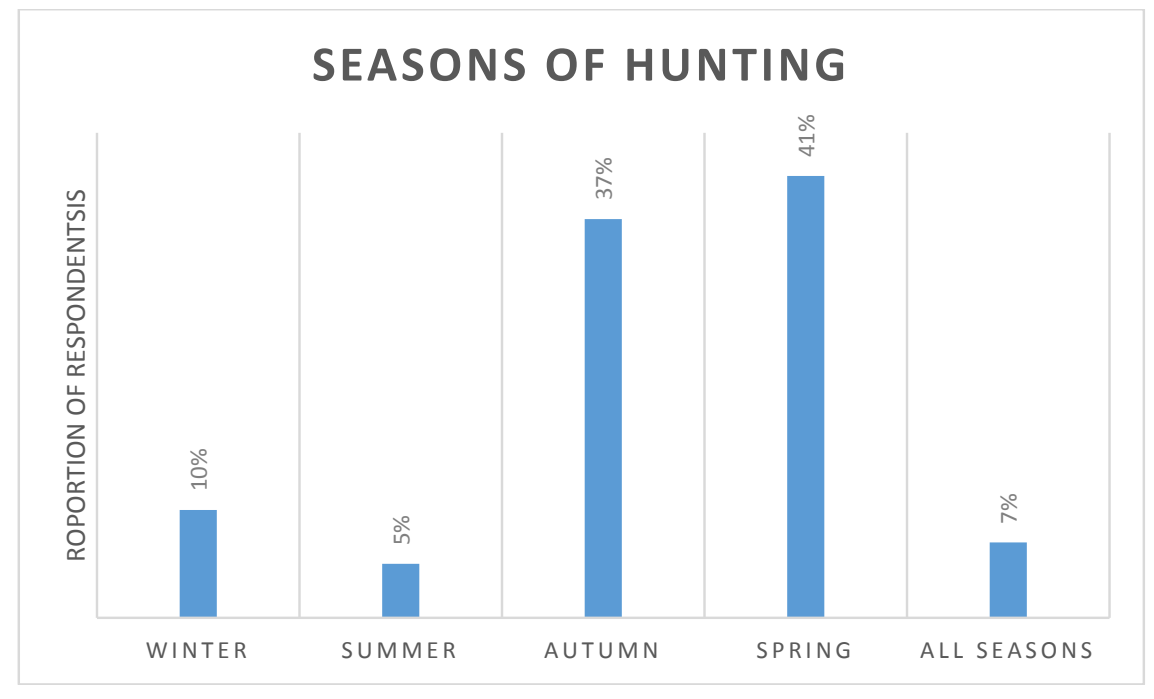

Figure 2. Distribution of responses regarding the main seasons for illegal hunting of wildlife in the northern section of Bardia National Park, Nepal $(n=41)$. 
Regarding the hunting methods employed, most interviewees (55\%) reported the combined use of dogs and handmade guns. Seventeen percent of respondents reported the use of guns only (no dogs, snares or baits). Fifteen percent reported the combined use of dogs, snares and guns ( $n=41$ for this question). Interviewees reported that dogs were used most effectively to chase grey langur monkeys and chital (spotted deer), these animals were then ambushed using either snares or guns. One respondent said, "we used dogs to chase guna (langur), all gunas gather in a tree, we fell tree and kill gunas."

In response to questions about the current motivations for hunting in the area, $62 \%$ of interviewees reported that hunting is for consumption of wild meat at a local level and $36 \%$ reported that hunting is for the purposes of obtaining wild meat for sale elsewhere. Only two percent of the interviewees reported that hunting is for recreation ( $n=42$ for this question, Figure 3). Interviewees reported various prices for wild meat, which averaged to NRs 613 ( US \$6) per kilogram. Participants reported that the sale of wild meat occurs locally in small markets along the highway. Chhinchu, Surkhet, Babai (Chepang), and Karnali Chisapani, are major local market places in the area. A few respondents indicated that meats were also supplied to the capital city, Kathmandu, $(\sim 550 \mathrm{~km}$ from the study area; more than $13 \mathrm{~h}$ by car, on difficult roads) as well. Occasionally, wild meat is supplied to nearer regional cities such as Kohalpur and Nepalgunj. These cities are nearly $60 \mathrm{~km}$ and $76 \mathrm{~km}$ away respectively from our study area. Some respondents $(n=4)$ reported that army officials come to buy the wild meat directly from local people. Such buyers are often in official vehicles, which pass easily through the security checks of the National Park. These products were reported to be destined for Kathmandu for consumption by high-level officials. In return, the locals who provide the wild meat were purported to be rewarded with jobs as soldiers in the national army (Nepalese army). As reported by one interviewee, "these officers do not hesitate to spend money on wild meat of jarayo (sambar), chital, bandel (wild boar) and mirga (barking deer); they never bargain the price offered."

Surprisingly, $48 \%$ of interviewees indicated that they preferred wild meat in their diet due to its unique taste, $35 \%$ said that needed wild meat for subsistence (to fulfill their protein needs) and $17 \%$ reported that they liked to eat wild meat for its medicinal value (Figure 4). There is a prominent belief that wild meat has general medicinal properties because wildlife consumes many wild herbs that possess medicinal properties, as indicated by the following statement from an interviewee: "guna's (langur) raw blood benefits neurological problems and the meat heals asthma disease, that is why we kill langurs."

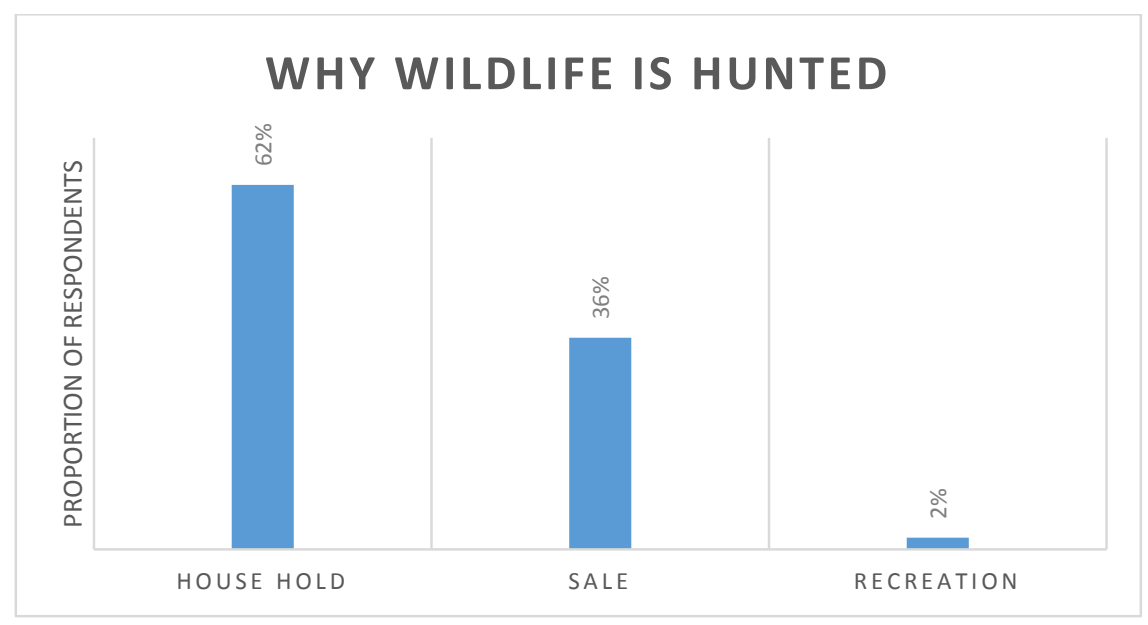

Figure 3. Distribution of responses regarding the drivers for illegal hunting of wildlife in the northern section of Bardia National Park, Nepal $(n=42)$.

Thirty-five percent of interviewees indicated that wild meat was used for subsistence. Almost all respondents (98\%) were aware that hunting of wildlife is illegal and that culprits can be apprehended and punished. Nearly all respondents $(97.5 \%)$ believed that people who are involved in hunting might abandon hunting if provided with the opportunity of some type of skill development training, which 
would lead to another source of income $(n=42)$. Further the respondents noted awareness activities, strict enforcement of hunting restriction by better patrolling and erecting park guard post in the region, livelihood support programs focusing on skill development activities, which can generate income and wildlife damage prevention programs could be beneficial in reducing the hunting for wild meat in this location.

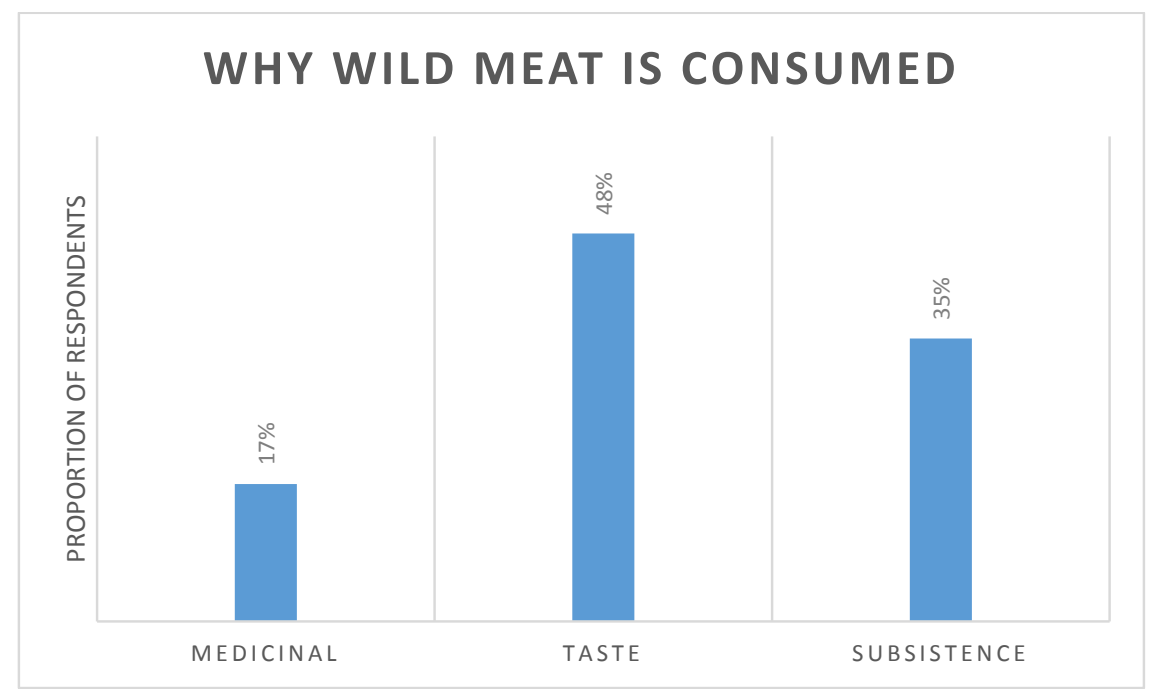

Figure 4. Distribution of responses regarding the reasons for consumption of wild meat in communities adjacent to Bardia National Park, Nepal. $(n=42)$.

Interviews with protected area managers $(n=5)$ also provided insights into the selling and trading of wild meat as an income source for local people. They considered that hunting for wild meat is more common in the northern section than in other parts of the park. Regarding the involvement of particular groups of people in hunting, there was some debate. The park warden expressed a view that the Darai Magar ethnic community and other members of the mixed community, who settled in the buffer zone area after encroaching the forestland, are the major groups involved in hunting. A conservation officer at a non-government conservation agency (National Trust for Nature Conservation) held a different view. He felt that there was not any particular community or group of people involved in hunting, rather almost all villagers were involved in hunting. This viewpoint corresponded more closely with that of the local people interviewed. An official of Bardia National Park believed that only males aged roughly between 25 and 40 are involved in illegal hunting. All protected area managers agreed that hunters are usually local residents; however, hunters from distant locations were known to have operated occasionally in the area.

\section{Discussion}

Our study area is home to carnivores including tiger, leopard, striped hyena, red fox, golden jackal and sloth bear. The tiger is listed as an Endangered Species [33] and prey population depletion is considered a major threat to tiger populations [20,34-36] and to other carnivores [37,38]. Prey population depletion reduces juvenile survival and carnivore density depends directly on prey species richness and abundance [39]. The removal of herbivores may also affect the vegetation pattern since large herbivores play roles in seed dispersal, which in turn affect the carnivore-herbivore assemblage [40]. For example, in our study area grey langur monkey is one of the major seed dispersal agents for tree species and this species is targeted for hunting due to its purported medicinal properties.

In Section 2 of Nepal's National Parks and Wildlife Conservation Act, 1973 hunting is defined as the act of chasing, capturing, harassing and killing of, or attempting to kill, wildlife. According to Section 5 of the same Act, hunting inside parks and reserve without a permit is banned. Similarly, 
in Section $49(n)$ of the Forest Act 1993, hunting is banned in any national forests without prior permission. National forests may be considered as forests outside of the national parks and wildlife reserves, which are managed and governed under the Forest Act 1993. These national forests have experienced extensive hunting pressure and the majority are devoid of large vertebrates. Before coming under the conservation jurisdiction of the buffer zone management committees in 2010, the areas surrounding the northern section of Bardia National Park were extensively hunted [41,42]. After the buffer zone was declared, illegal hunting reduced remarkably, largely due to the continuous and vigorous efforts of Bardia National Park staff and partner conservation agencies. In our study, respondents told us that hunting still occurs. Records held by Bardia National Park also show that hunting is currently occurring in the area. According to these records, nine different cases of prey hunting in the northern part of Bardia National Park, involving 32 people, have been documented since the area was incorporated into the buffer zone. While our transect searches did not uncover any physical evidence of hunting, a fresh meat-drying hut and remnants of Sambar carcass found near the Babai (Chepang) during a routine patrol by national park staff in May 2015, is also documented in the park records. A more intensive search that extended further into forested areas may have resulted in some physical evidence of hunting.

A Conservation Officer of the National Trust for Nature Conservation, Bardia Conservation Program observed that although hunting has continued in the area after 2010, the mode of hunting has changed. Previously people hunted openly; but now they hunt covertly. Before the establishment of the National Park and the buffer zone, small groups of people (8-12) used to go hunting; however, this tradition no longer occurs, and now people hunt alone or in groups of two, sometimes accompanied by a dog. The smaller parties are thought to be less likely to be detected by the National Park authority and the more covert nature of present-day hunting leaves less evidence.

The reasons for hunting also seem to have changed. Reports from local people interviewed during our study indicate that hunting of prey species in the northern part of the park was previously for traditional/subsistence reasons, with meat products consumed locally. However, after the highway was built, meat and animal parts are sold by local hunters at local markets along the highway. This involves considerable effort by the hunters, since the highway is some distance away from the villages, and the villages can only be reached by foot. Occasionally, purchasers are located in regional centers (Kohalpur, Nepalgunj or Surkhet) or even as far away as Kathmandu. The price of wild meat increases up to NRs 2000 ( US \$ 20) per kg if it is sold in Surkhet or Nepalgunj or Kathmandu; but there is a higher risk of being apprehended by authorities. Occasionally, respondents mentioned the sale of skins and antlers of deer. Skins of these ungulates are used in making local musical instruments such as madal and damaha. One respondent informed us that some skins were sold to a processing factory located in Nepalgunj; however, he/she was unaware of the price of the skins.

Not all of the products of hunting are sold outside of the area. Interviews with protected area managers (including Park Rangers and officers of conservation agencies) revealed that due to the high unemployment rate and associated poverty in the study area, some people hunt wildlife to fulfill the protein requirements of their diet. Malla [42] reported that this area suffers from poverty: agriculture production is hardly enough for three to five months and many youths seasonally migrate to India for seasonal jobs for around two to three months to earn household needs. Although participants' responses regarding the need for, and possible conservation benefits of, skills training are not necessarily reliable, these observations support the case for improved employment opportunities for local people in the interests of sustainable development and wildlife conservation. Thus our project team implemented a skills training program in late 2015, which was well attended.

Some respondents reported that crop raiding by wild boar and monkeys is also a driver for hunting of these animals, where the primary objective is to reduce the incidence of crop raiding rather than to acquire wild meat. Similar motivations were reported in a study by Mittermeier [43] and Paudel [41].

The traditional beliefs around the medicinal values of wild meat, including taking fresh blood of the grey langur monkey to heal asthma, is a key driver for hunting. Similar results were reported in 
a study by Paudel [41] in localities adjacent to our study site. Poverty, lower levels of education and the remoteness of the area (no motorable road), all of which reduce access to health service facilities, are likely influences in the killing of wildlife for medicinal purposes.

In our study, respondents reported that hunting mostly occurred during the festive season of Dashain, which falls in October. Dashain is an important Hindu festival and meat is a major food item in each household at this time. Therefore, hunting events are frequent around the time of this festival. In addition, during the Dashain period, National Park staff vigilance is very much reduced as this is a holiday period. Hunters therefore have easy access into the forests. Protected area managers also noticed that other illegal activities such as timber smuggling also increase during the Dashain period.

As hand-made guns are made in the community, it is not difficult for local people to make or obtain a weapon and use it for hunting. A self-identified ex-hunter who is now the chairman of a community based anti-poaching unit explained the hunting practice as follows:

"In our village (Taranga) every household possesses at least one locally hand-made gun. During the festive season (Dashain and maghee), we fire the guns in the air. For instance, in the past before starting Tika, the village leader used to fire the gun and only after that, all other villagers officially begin the Tika. Therefore, the gun is a part of the culture. Guns are also used for hunting wild meat. We used to hunt game in small groups of people. After killing the wildlife we used to play music and dance. This was our ethnic tradition (of the Magar community) in the past, which nowadays has been stopped due to the establishment of the National Park. Wild yam and wild meats are important parts of these festivals."

Occasional prey poaching is present in other parts of the Bardia National Park but the northern section (our study site) has more incidents of prey hunting [44]. Four reasons for the high incidence of hunting in this part of the park and buffer zone area were provided by the Chief Conservation Officer of the Park during interviews:

(1) no park staff in the area

(2) poverty and a lack of job opportunities

(3) remoteness

(4) lack of awareness, about negative impacts of hunting on conservation

A Conservation Officer at Bardia National Park had similar thoughts regarding the reasons behind continued illegal game hunting for wild meat in the National Park. He added that the poor intelligence network compared with other areas of the park, might be an additional reason for continuation of hunting in the northern section of the park.

Many authors claim that, under some circumstances, legalized hunting can have positive effects on game management and conservation. Carefully monitored and controlled hunting can result in population management and significant revenue may be earned from permit fees and then directed to fund conservation activities $[17,19]$. On the contrary, illegal hunting typically results in population depletion and in severe scenario may lead to the loss of species $[1,6,10]$ and to loss of revenue due to reduced opportunities for wildlife tourism.

Our study involved a relatively low number of informants, a common limitation where information about illegal activities is sought. We are therefore cautious about generalizing and over-interpreting our results, but recognize that this study provides important preliminary information about illegal hunting activities in Bardia National Park, which might be useful to park managers in order to plan conservation activities, and to researchers to inform further studies. The robustness of our results has been further improved by incorporating secondary information from the national park authority. 


\section{Conclusions and Implications for Carnivore Conservation}

Protection of prey species is clearly important in conservation of carnivores. When prey levels are depleted, even small-scale poaching might accelerate the rate of extinction. Therefore, control of hunting of prey species should be a conservation priority alongside efforts to curb the poaching of endangered carnivore species. This study has demonstrated that illegal hunting of carnivore prey species is occurring in the northern section of Bardia National Park in Nepal. Hunting occurs predominantly in spring and autumn and is associated with festival times. The introduction of a road network in the region has provided opportunities for local people to sell wild meat, so that hunting now provides a means to supplement limited incomes for local people. Households also use wild meat as a protein source and for perceived medicinal benefits. Locally handmade guns and dogs are used during hunting, which protected area managers associate with a lack of presence of park authorities, remoteness and underdevelopment and poverty of the community. Participants in our study agreed that skills development training for local community members might reduce the dependency of local people on wild meat, for both household consumption and for income, thereby reducing illegal hunting. Examples could include training in solar panel maintenance, household electricity wiring, modern farming technologies, plumbing, etc. Development of skills such as these would allow community members to earn a livelihood that does not rely on hunting, and alternative sources of employment would increase the opportunity costs of poaching. Our project conducted a trial skills training program focused on solar panel and household electricity maintenance. There is considerable scope to extend such programs, perhaps even to include wildlife tourism skills, promulgating the message that wildlife conservation brings economic and ecological benefits to the region. Education of local people with regard to appropriate treatment of diseases such as asthma, and access to appropriate health information, facilities and medication will also help to address the hunting of wild animals for medicinal purposes.

Acknowledgments: We are grateful to the Nepalese Department of National Parks and Wildlife Conservation for granting permission to conduct this study. We are indebted to local communities and officials who provided responses during our interviews. We acknowledge logistic and other support from the staff of Bardia National Park and Bardia Conservation Programme (National Trust for Nature Conservation) during the study. We are grateful to the Rufford Foundation for Nature Conservation for providing financial support (grant No. 16119-B) to conduct this study. We are thankful to Milan Dhungana for his efforts in preparing the study area map. The study was carried out with the approval of Federation University Australia's Human Research Ethics Committee (Project No. B15-051). Finally, we thank two anonymous reviewers for their feedback to improve the quality of the manuscript.

Author Contributions: Babu and Wendy designed the research and prepared the manuscript. Babu collected primary data (interview) and analysed the data. Ambika collected secondary data and contributed in preparing manuscript.

Conflicts of Interest: The authors declare no conflict of interests.

\section{Appendix A}

Table A1. List of plants and animals named in the text.

\begin{tabular}{|c|c|c|c|c|}
\hline Common Name/English & $\begin{array}{c}\text { Common } \\
\text { Name/Nepali }\end{array}$ & Scientific Name & $\begin{array}{c}\text { International } \\
\text { Conservation Status * }\end{array}$ & $\begin{array}{l}\text { Protected by } \\
\text { Law in } \\
\text { Nepal } * *\end{array}$ \\
\hline \multicolumn{5}{|c|}{ Mammals } \\
\hline \multirow{2}{*}{$\begin{array}{c}\text { Asian elephant } \\
\text { Barking deer or Southern Red } \\
\text { Muntjak }\end{array}$} & Hatti & Elephas maximus & Endangered & Yes \\
\hline & Ratuwa & Muntiacus muntjak & Least concern & \\
\hline Bluebuck or Nilgai & Nilgai & Boselaphus tragocamelus & Least concern & \\
\hline Four-horned antelope & Chauka & Tetraceros quadricornis & Vulnerable & Yes \\
\hline Ganges River dolphin & Dalfin & Platanista gangetica & Endangered & Yes \\
\hline Golden jackal & Syal & Canis aureus & Least concern & \\
\hline Greater one-horned rhinoceros & Gaida & Rhinoceros unicornis & Vulnerable & Yes \\
\hline $\begin{array}{c}\text { Himalayan Goral } \\
\text { Hog deer }\end{array}$ & Ghoral & $\begin{array}{l}\text { Naemorhedus goral } \\
\text { Axis porcinus }\end{array}$ & $\begin{array}{l}\text { Near threatened } \\
\text { Endangered }\end{array}$ & \\
\hline
\end{tabular}


Table A1. Cont.

\begin{tabular}{|c|c|c|c|c|}
\hline Common Name/English & $\begin{array}{c}\text { Common } \\
\text { Name/Nepali }\end{array}$ & Scientific Name & $\begin{array}{c}\text { International } \\
\text { Conservation Status * }\end{array}$ & $\begin{array}{c}\text { Protected by } \\
\text { Law in } \\
\text { Nepal }\end{array}$ \\
\hline \multicolumn{5}{|c|}{ Mammals } \\
\hline Indian crested porcupine & Dumsi & Hystrix indica & Least concern & \\
\hline Leopard & Chituwa & Panthera pardus & Near threatened & \\
\hline $\begin{array}{c}\text { Northern Plains grey langur or } \\
\text { grey langur }\end{array}$ & Dhedu bandar/guna & Semnopithecus entellus & Least concern & \\
\hline Red fox & Fyauro & Vulpes vulpes & Least concern & \\
\hline Rhesus monkey & Rato bandar & Macaca mulata & Least concern & \\
\hline Sambar deer & Jarayo & Rusa unicolor & Vulnerable & \\
\hline Sloth bear & Kathe bhalu & Melursus ursinus & Vulnerable & \\
\hline Spotted deer & Chital & Axis axis & Least concern & \\
\hline Striped Hyaena & Hudar & Hyaena hyaena & Near threatened & Yes \\
\hline Swamp deer & Barahsingha & Rucervus duvaucelii & Vulnerable & Yes \\
\hline Tiger & Bagh & Panthera tigris & Endangered & Yes \\
\hline Wild boar & Bandel & Sus scrofa & Least concern & \\
\hline Wolf (Gray wolf) & Bwanso & Canis lupus & Least concern & Yes \\
\hline \multicolumn{5}{|c|}{ Reptiles } \\
\hline Burmese python or python & Ajingar & Python bivittatus & Vulnerable & \\
\hline Gharial & Ghadial gohi & Gavialis gangeticus & Critically endangered & Yes \\
\hline Mugger or Muggar crocodile & Gohi & Crocodylus palustris & Vulnerable & \\
\hline \multicolumn{5}{|c|}{ Birds } \\
\hline Bengal florican & & Houbaropsis bengalensis & Critically endangered & Yes \\
\hline Great hornbill & Dhanesh & Buceros bicornis & Near threatened & Yes \\
\hline Khalij pheasant & Kalij & Lophura leucomelanos & Least concern & \\
\hline \multicolumn{5}{|c|}{ Trees } \\
\hline Betel-nut palm or Black cutch & Khayar & Senegalia catechu & Not assessed & \\
\hline Chir pine & Sallo & Pinus roxburghii & Least concern & \\
\hline False white teak & Gutel & Mallotus nudiflorus & Not assessed & \\
\hline Kamala tree or Red kamala & Sindure & Mallotus philippensis & Not assessed & \\
\hline North Indian rosewood & Sisau & Dalbergia sissoo & Not assessed & \\
\hline Kharsu oak or Brown oak & Khasru & Quercus semecarpifolia & Not assessed & \\
\hline Sal tree & Sal & Shorea robusta & Least concern & \\
\hline
\end{tabular}

* IUCN The IUCN Red List of Threatened Species. Version 2015-4. (www.iucnredlist.org, accessed on 3 April

2016); $*$ GoN (Government of Nepal) National Parks and Wildlife Conservation Act 1973, Nepal.

\section{References}

1. Corlett, R.T. The impact of hunting on the mammalian fauna of tropical Asian forests. Biotropica 2007, 39, 292-303. [CrossRef]

2. Diamond, J. Overview of recent extinctions. In Conservation for the Twenty-First Century; Oxford University Press: New York, NY, USA, 1989; pp. 37-41.

3. Rangarajan, M. India's Wildlife History: An Introduction; Orient, Blackswan: Telangana, India, 2011.

4. Robinson, J.G.; Redford, K.H. Neotropical Wildlife Use and Conservation; University of Chicago Press: Chicago, IL, USA, 1991.

5. Nielsen, M.R. Importance, cause and effect of bushmeat hunting in the Udzungwa Mountains, Tanzania: Implications for community based wildlife management. Biol. Conserv. 2006, 128, 509-516. [CrossRef]

6. Robinson, J.G.; Bennett, E.L. Having your wildlife and eating it too: An analysis of hunting sustainability across tropical ecosystems. Anim. Conserv. 2004, 7, 397-408. [CrossRef]

7. Woodroffe, R. Predators and people: Using human densities to interpret declines of large carnivores. Anim. Conserv. 2000, 3, 165-173. [CrossRef]

8. Check, E. Conservation biology: The tiger's retreat. Nature 2006, 441, 927-930. [CrossRef] [PubMed]

9. Holdaway, R.N.; Jacomb, C. Rapid extinction of the moas (Aves: Dinornithiformes): Model, test, and implications. Science 2000, 287, 2250-2254. [CrossRef] [PubMed]

10. Milner-Gulland, E.J.; Bennett, E.L. Wild meat: The bigger picture. Trends Ecol. Evol. 2002, 18, 351-357. [CrossRef]

11. Rao, M.; Htun, S.; Zaw, T.; Myint, T. Hunting, livelihoods and declining wildlife in the Hponkanrazi Wildlife Sanctuary, North Myanmar. Environ. Manag. 2010, 46, 143-153. [CrossRef] [PubMed] 
12. Bajracharya, S.B.; Furley, P.A.; Newton, A.C. Effectiveness of community involvement in delivering conservation benefits to the Annapurna Conservation Area, Nepal. Environ. Conserv. 2005, 32, $239-247$. [CrossRef]

13. Bennett, E.L.; Rao, M. Wild meat consumption in Asian tropical forest countries: Is this a glimpse of the future for Africa? In Links between Biodiversity, Conservation, Livelihoods and Food Security: The Sustainable Use of Wild Species for Meat; Mainka, S., Trivedi, M., Eds.; IUCN Species Survival Commission: Virginia, VA, USA, 2002; pp. 39-44.

14. GoN (Government of Nepal). National Parks and Wildlife Conservation Regulation 1976. Available online: http:/ /www.forestaction.org/app/webroot/js/tinymce/editor/plugins/filemanager/ files/National_Park_Act_1973_Nepal\%20(1).pdf (accessed on 1 November 2016).

15. GoN (Government of Nepal). National Parks and Wildlife Conservation Act 1973. Available online: http:// www.unesco.org/culture/natlaws/media/pdf/australia/australia_act_31_07_1975_eng_orof.pdf (accessed 1 November 2016).

16. GoN (Government of Nepal). Forest Act 1993. Available online: http:/ /www.forestrynepal.org/images/ Forest_Act_of_Nepal_1993.pdf (accessed 1 November 2016).

17. Aryal, A.; Dhakal, M.; Yadav, B.P.; Shrestha, U.B.; Bencini, R.; Raubenheimer, D.; Ji, W. Is trophy hunting bharal (blue sheep) and Himalayan tahr contributing to their conservation in Nepal? Hystrix Ital. J. Mammal. 2015, 26, 85-88.

18. Mishra, H.R. Balancing human needs and conservation in Nepal's Royal Chitwan Park. Ambio 1982, $246-251$.

19. Loveridge, A.J.; Valiex, M.; Chapron, G.; Davidson, Z.; Mtare, G.; Macdonald, D.W. Conservation of large predator populations: Demographic and spatial responses of African lions to the intensiry of trophy hunting. Biol. Conserv. 2016. [CrossRef]

20. Karanth, K.U.; Stith, B.M. Prey depletion as a critical determinant of tiger population viability. In Riding the Tiger: Tiger Conservation in Human-Dominated Landscapes; Seidensticker, J., Christie, S., Jackson, P., Eds.; Cambridge University Press: Cambridge, UK, 1999; pp. 100-113.

21. Foster, R.J.; Harmsen, B.J.; Valdes, B.; Pomilla, C.; Doncaster, C. Food habits of sympatric jaguars and pumas across a gradient of human disturbance. J. Zool. 2010, 280, 309-318. [CrossRef]

22. Kala, C.P.; Kothari, K.K. Livestock predation by common leopard in Binsar Wildlife Sanctuary, India: Human-wildlife conflicts and conservation issues. Hum.-Wildl. Interact. 2013, 7, 325-333.

23. Madhusudan, M.; Karanth, K.U. Local hunting and the conservation of large mammals in India. Ambio 2002, 31, 49-54. [CrossRef] [PubMed]

24. Baral, H.S. Threatened Birds of Nepal; Bird Conservation Nepal: Kathmandu, Nepal, 1996.

25. Bhattarai, B.R.; Fischer, K. Human-tiger Panthera tigris conflict and its perception in Bardia National Park, Nepal. Oryx 2014, 48, 522-528. [CrossRef]

26. Brown, K. Plain tales from the grasslands: Extraction, value and utilization of biomass in Royal BardiaNational Park, Nepal. Biodivers. Conserv. 1997, 6, 59-74. [CrossRef]

27. Dinerstein, E. An ecological survey of the Royal Karnali-Bardia Wildlife Reserve, Nepal. Part I: Vegetation, modifying factors, and successional relationships. Biol. Conserv. 1979, 15, 127-150. [CrossRef]

28. Thapa, S.; Chapman, D.S. Impacts of resource extraction on forest structure and diversity in Bardia National Park, Nepal. For. Ecol. Manag. 2010, 259, 641-649. [CrossRef]

29. Punch, K.F. Introduction to Social Research: Quantitative and Qualitative Approaches; Sage publication: London, UK, 2013.

30. John, F.A.S.; Edwards-Jones, G.; Gibbons, J.M.; Jones, J.P. Testing novel methods for assessing rule breaking in conservation. Biol. Conserv. 2010, 143, 1025-1030. [CrossRef]

31. Nuno, A.; St. John, F.A.V. How to ask sensitive questions in Conservation: A review of specialized questioning technique. Biol. Conserv. 2015, 189, 5-15. [CrossRef]

32. Barnet, J. Sensitive questions and response effects: An evaluation. J. Manag. Psychol. 1998, 13, 63-68. [CrossRef]

33. Panthera Tigris. The IUCN Red List of Threatened Species. Available online: http://www.iucnredlist.org/ details/15955/0 (accessed on 1 November 2016).

34. Damania, R.; Stringer, R.; Karanth, K.U.; Stith, B. The economics of protecting tiger populations: Linking household behavior to poaching and prey depletion. Land Econ. 2003, 79, 198-216. [CrossRef] 
35. Karanth, K.U.; Nichols, J.D.; Kumar, N.S.; Link, W.A.; Hines, J.E. Tigers and their prey: Predicting carnivore densities from prey abundance. Proc. Natl. Acad. Sci. USA 2004, 101, 4854-4858. [CrossRef] [PubMed]

36. Ramakrishnan, U.; Coss, R.G.; Pelkey, N.W. Tiger decline caused by the reduction of large ungulate prey: Evidence from a study of leopard diets in southern India. Biol. Conserv. 1999, 89, 113-120. [CrossRef]

37. Erlinge, S. Distribution, territoriality and numbers of the weasel Mustela nivalis in relation to prey abundance. Oikos 1974, 308-314. [CrossRef]

38. Hofer, H.; East, M. Population dynamics, population size, and the commuting system of Serengeti spotted hyenas. In Serengeti II: Dynamics, Management, and Conservation of an Ecosystem; University of Chicago Press: Chicago, IL, USA, 1995; pp. 332-363.

39. Fuller, T.K.; Sievert, P.R. Carnivore Demography and the Consequences of Changes in Prey Availability; Cambridge University Press: Cambridge, UK, 2001; pp. 163-178.

40. Corlett, R.T. Frugivory and seed dispersal by vertebrates in the Oriental (Indomalayan) Region. Biol. Rev. Camb. Philos. Soc. 1998, 73, 413-448. [CrossRef] [PubMed]

41. Paudel, P.K. Challenges to wildlife conservation posed by hunting in non-protected areas north of the Bardia National Park. In Himalayan Biodiversity in the Changing World; Springer: New York, NY, USA, 2012; pp. 177-195.

42. Malla, S. Estimating the Status and Impact of Hunting on Tiger Prey in Bardia National Park, Nepal. Master's Thesis, Saurastra University, Gujarat, India, 22 August 2009.

43. Mittermeier, R.A. Effects of hunting on rain forest primates. In Primate Conservation in the Tropical Rain Forest; Cambridge University Press: Cambridge, England, 1987; pp. 109-146.

44. Ram, C.K.; Chief Conservation Officer, Bardia National Park, Nepal, Phone:+977 56411024. Personal communication.

(C) 2016 by the authors; licensee MDPI, Basel, Switzerland. This article is an open access article distributed under the terms and conditions of the Creative Commons Attribution (CC-BY) license (http:/ / creativecommons.org/licenses/by/4.0/). 